\title{
A Novel Approach to Use Soil-Cement Piles for Steel Sheet Pile Walls in Deep Excavations
}

\author{
Tuan Anh Nguyen ${ }^{1, *}$, Dat Thanh Nguyen ${ }^{2}$, Anh Duc Nguyen ${ }^{1}$ \\ ${ }^{1}$ Faculty of Transportation Engineering, Ho Chi Minh City University of Transport, Ho Chi Minh City, Viet Nam \\ ${ }^{2}$ Faculty of Civil Engineering, Ho Chi Minh City University of Transport, Ho Chi Minh City, Viet Nam
}

Received December 6, 2020; Revised January 4, 2021; Accepted February 24, 2021

\section{Cite This Paper in the following Citation Styles}

(a): [1] Tuan Anh Nguyen, Dat Thanh Nguyen, Anh Duc Nguyen , "A Novel Approach to Use Soil-Cement Piles for Steel Sheet Pile Walls in Deep Excavations," Civil Engineering and Architecture, Vol. 9, No. 2, pp. 301 - 316, 2021. DOI: 10.13189/cea.2021.090204.

(b): Tuan Anh Nguyen, Dat Thanh Nguyen, Anh Duc Nguyen (2021). A Novel Approach to Use Soil-Cement Piles for Steel Sheet Pile Walls in Deep Excavations. Civil Engineering and Architecture, 9(2), 301 - 316. DOI: 10.13189/cea.2021.090204.

Copyright $\bigcirc 2021$ by authors, all rights reserved. Authors agree that this article remains permanently open access under the terms of the Creative Commons Attribution License 4.0 International License

\begin{abstract}
In recent years, owing to advances in technology, excavation pits have shown increased improvements. Taking advantage of advanced solutions combined with traditional ones has brought about considerable advantages for construction contractors and saves on expenses to carry out construction projects. Owing to their ability to analyze geotechnical problems, several calculation and simulation software, such as Plaxis, Bentley, along with many others, have grown in popularity. Among them, Midas is one such software, which is a set of solutions developed by the MIDAS IT company and is widely applied in many constructions. The authors evaluated the ability to use Midas software to calculate the stability of a wall in a deep excavation pit for the Ho Chi Minh City Water Environment Improvement Project. The results of these researches reveal that combining soil-cement piles and steel sheet piles decreases the internal forces in sheet steel pile walls. At the same time, this solution not only reduces horizontal displacement but also keeps the settlement of the soil around the excavation pit within the permissible range, which helps to ensure that the adjacent pavements are stable and will not crack. The results of this study can be applied to similar geological constructions.
\end{abstract}

Keywords Deep Excavation, FEM, Displacement, Deep Cement Mixing Columns, Stability

\section{Introduction}

Tunneling construction has become an indispensable trend for traffic systems by exploring underground space in modern cities. It is the case, however, that each project has different conditions of geology, hydrography, tunnel structure, etc [11]. So profound research is constantly needed to assess the influences of tunneling on adjacent buildings.

Deep cement mixing columns (DCMCs) comprise the soil at the construction site and cement, which is grouted to the ground using the injection grouting pump. The drill bit is drilled down to loosen the soil until it reaches the depth of the soil layer that needs to be reinforced. After that, the drill bit then comes back and moves up. In the process of moving up, cement is grouted into the ground. This is a new technology applied in flooded areas where other types of columns do not meet the requirements. $[1,16,21]$

In Ho Chi Minh City, the rapid pace of urban development has narrowed the construction area. The technical infrastructure systems are being upgraded and improved due to the rapid development of urban areas. As a result, the deep excavation of pits is frequent and inevitable. [2]

Owing to their versatility and usefulness, sheet steel pile combined with a bracing support to stabilize the pit is often applied as a solution; however, among other problems, at the joints of steel sheet piles, water can often 
leak and spill into the excavation pit, thus causing difficulties during construction. [4]

The solution of soil-cement pile walls is also frequently used in the construction of basements; however, due to the limited horizontal shearing resistance, they are only applicable to pits that are not too deep. [13,19]

Currently, nobody has used soil-cement piles with steel sheet piles in a project; therefore, the authors proposed a simulation combining soil-cement piles with steel sheet piles to find a better solution.

Many authors have studied the factors affecting the horizontal displacement of the diaphragm wall in a deep excavation pit, including pre-stressing in the strut system, factors related to construction issues, and factors related to design issues. [14,17]

Chang Yu Ou et al. (1993) [5] studied the relationship between the depth of a pit and the horizontal displacement of the diaphragm wall in the deep excavation pit. According to the results of this study, the largest horizontal displacement of the diaphragm wall in the deep excavation pit varies between 0.2 and $0.5 \%$ of the depth of the pit, as shown in Fig.1.

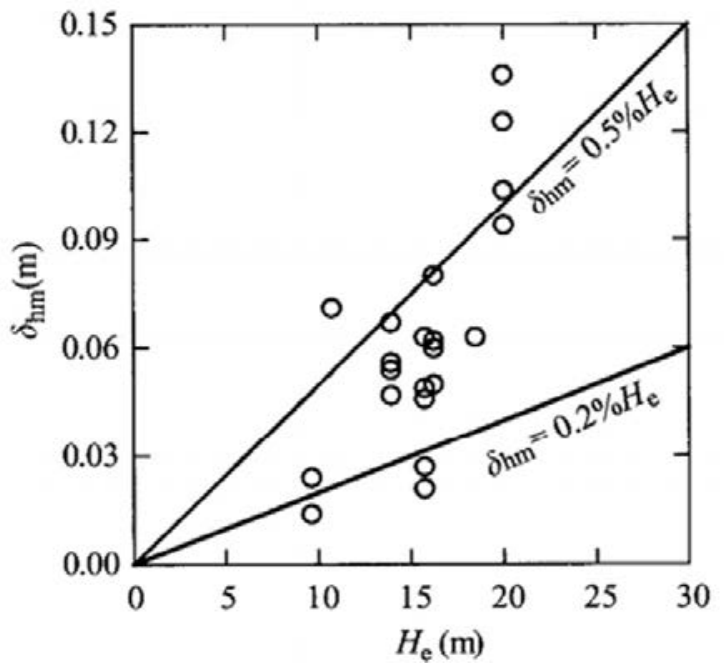

Figure 1. Relationship between the maximum horizontal displacement of the diaphragm wall and depth of excavation pit [4]

Further, Chang $\mathrm{Yu}$ Ou (2006) mentioned the relationship between the depth of the diaphragm wall $\left(\mathrm{H}_{\mathrm{p}}\right)$ and the displacement of the diaphragm wall, as shown in
Fig. 2 [5]. The authors analyzed the horizontal displacement of the diaphragm wall in a $20 \mathrm{~m}$ deep excavation pit using FEM (Fig.3).

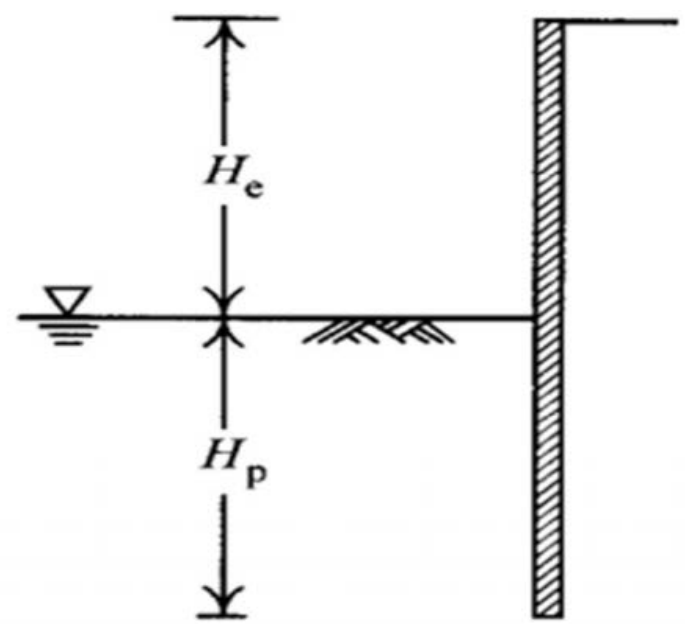

Figure 2. $\mathrm{H}_{\mathrm{p}}$ wall depth, Chang Yu Ou (2006)
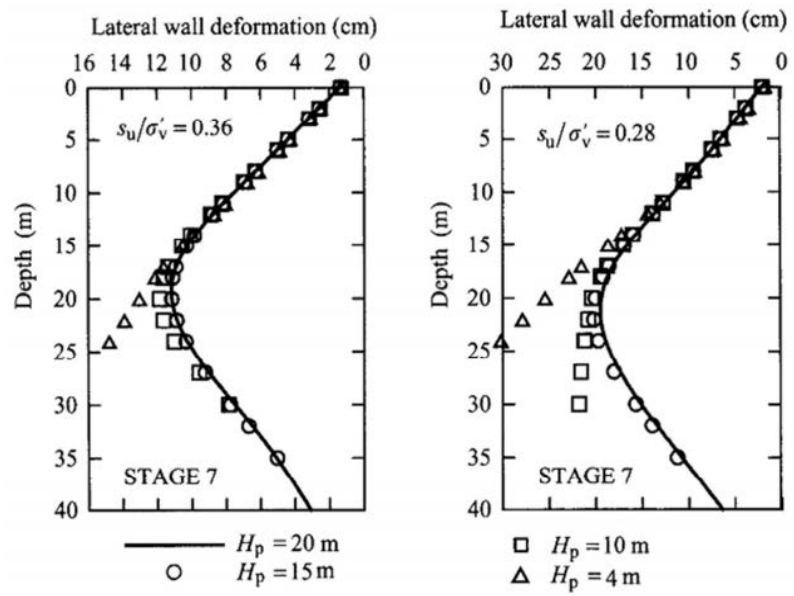

Figure 3. Correlation between fixed wall depth and horizontal displacement of a wall [5]

When the struts are not filled, the wall will move like a cantilever. When the struts are installed, the stiffness of the struts is large enough to allow the wall to move around the junction between the wall and the struts and the largest horizontal displacement of the wall, located near the bottom of the pit. The displacement type of a wall is shown in Fig. 4 and Fig. 5. 


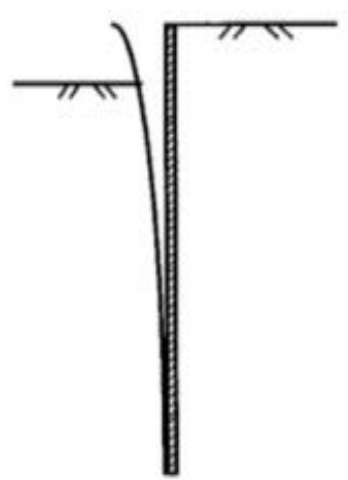

(a)

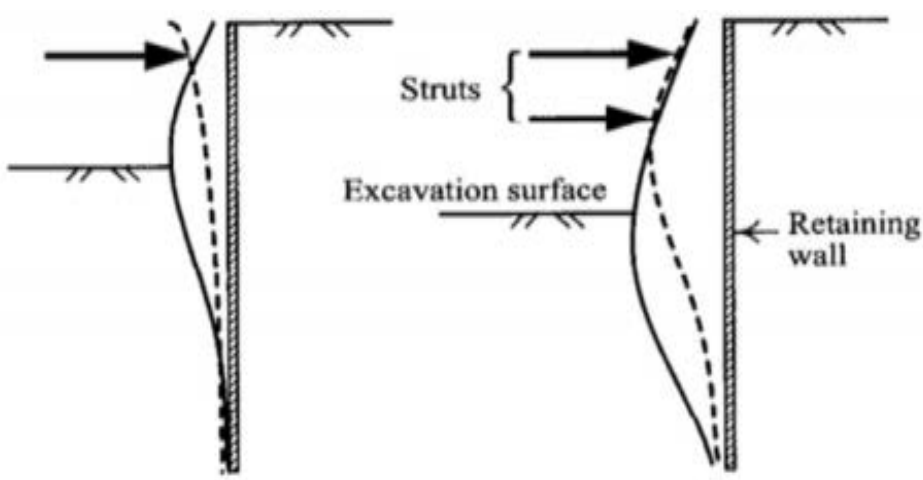

(b)

(c)

Figure 4. Displacement type of a wall in a case where the strut stiffness is large enough. (a) stage without struts, (b) stage with struts, (c) stage with multiple struts installed [5].

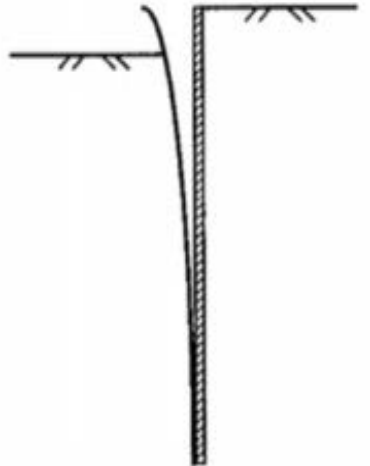

(a)

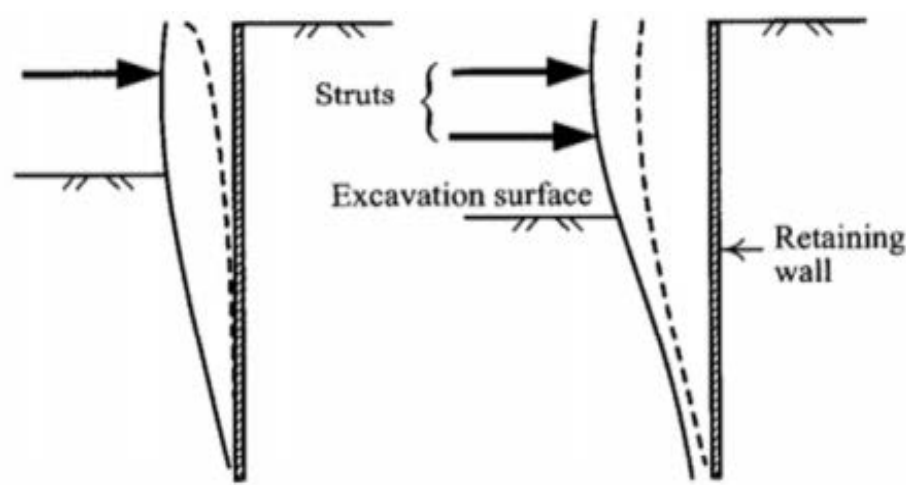

(b)

(c)

Figure 5. Displacement type of a wall in a case where the strut stiffness is not large enough. (a) stage without struts, (b) stage with struts, (c) stage with multiple struts installed [5].

Clough and O'Rourke (1990) discussed safety in a study of its effect on the horizontal displacement of the diaphragm wall in a deep excavation pit [6]. The researchers provided a correlation between the factor of safety against basal heave, the stiffness of the diaphragm wall, and the support system with the maximum horizontal displacement of the wall through Fig. 6 .

In which $F^{b}$ is the factor of safety against the basal heave.

In order for the model to be able to give reliable deformation and stress distributions, the modeling area limits also need to be rational. The rationality here is understood that the model area must be large enough to cover the interaction between the deep excavation pit and the surrounding ground. K.J. Bakker (2005) proposed limiting the model area when analyzing deep excavation pits through the Plaxis software [3]. According to Bakker, modeling area limits depend on the width of the pit, the depth of the pit, and the length of the diaphragm wall. Helmut F. Schweiger (2002) studied the effect of modeling area limits on the analysis results of the horizontal displacement of diaphragm walls. Helmut F. Schweiger analyzed a deep excavation pit with different modeling area limits. From the research results, Helmut F. Schweiger commented that once the limit of the modeling area is reached, the expansion of the modeling area limit does not significantly affect the results of horizontal displacement analysis of the diaphragm wall in the excavation pit.

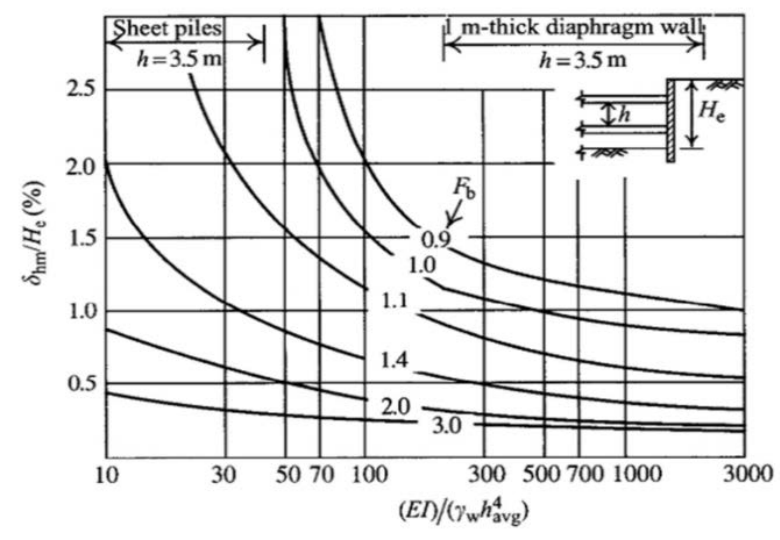

Figure 6. Correlation between the factor of safety against basal heave, the stiffness of the diaphragm wall and the support system with the maximum horizontal displacement of the wall [6]. 
B. Gebreselassie and H.G. Kempfert (2006) [8] conducted a sensitivity analysis of the parameters of the Hardening Soil model to the results of the behavior of a deep excavation pit in a normally consolidated clay foundation. The parameters that B. Gebreselassie and H.G. Kempfert conducted for sensitivity analysis were $v_{u r}$, $k_{0}^{n c}, E_{50}^{r e f}, E_{u r}^{r e f}, E_{o e d}^{r e f}$, and $R_{f}$. Parameter sensitivity was analyzed changing one parameter while keeping the remaining parameters fixed. The analysis results in each case were compared to draw conclusions. According to B. Gebreselassie and H.G. Kempfert, the most sensitive parameter for the horizontal displacement analysis of the basement diaphragm wall is $E_{50}$. The largest horizontal displacement of the diaphragm wall changes from $45-24 \%$ in accordance with the range of $E_{50}$ variation of $\pm 50 \%$.

The factor $k_{0}^{n c}$ also has a significant influence on the horizontal displacement of the diaphragm wall in a deep excavation pit. Trung, N.D. and Phan, V. (2011) [18] analyzed the sensitivity of loading and unloading module parameters in the Hardening Soil model to the horizontal displacement of the diaphragm wall. Value $\mathrm{E}_{\mathrm{ur}}$ changes by $3 \mathrm{E}_{50}, 4 \mathrm{E}_{50}, 5 \mathrm{E}_{50}$ to analyze the horizontal displacement of the diaphragm wall during the excavation phase. The analysis results show that the effect of the value fluctuation of the horizontal displacement of the diaphragm wall is negligible.

Tan et al. (2001) [15] studied the correlation between the module E parameter in the Hardening Soil model of Plaxis and the SPT-N index by back analysis of some deep excavation works on the sedimentary foundation of Kenny Hill in Kuala Lumpur, Malaysia, and sea mud in western Malaysia.

According to the above studies, hardness parameters affect the analysis results of the basement wall horizontal displacement the most. However, determining the parameters for the ground models according to the model's theory is an impossible task because in reality the geological data as well as the results of laboratory and field experiments are not always complete and correct. Therefore, it is essential to determine the range of fluctuations for these parameters for each soil type or their correlation with other physical and mechanical parameters. This range of fluctuation and correlation was studied through the back analysis of deep excavation and the comparison of the monitoring results of some national and international authors.

An, C.N. (2009) [1] used the correlation between SPT-N and modulus E in the Mohr Coulomb model to analyze the simultaneous work between the ground and the diaphragm wall of the water pumping station at the Nhieu Loc - Thi Nghe wastewater treatment system in Ho Chi Minh City.

Hai, N.V. and Nghia, L.T. (2007) [7] analyzed a deep excavation pit and its diaphragm wall with soil-cement piles and provided the variation of modulus $\mathrm{E}$ in the Mohr Coulomb model for the soft soil layer in District 7, Ho Chi Minh city, Vietnam.

This paper presents the application of steel sheet piles combined with soil-cement piles to stabilize a deep excavation pit's wall for the Ho Chi Minh City Water Environment Improvement Project.

\section{Materials and Methods}

\subsection{Simple Method}

The simple method is based on past cases that had produced graphs of the relationship between different factors and the horizontal displacement of the diaphragm wall. Ou et al. (1993) [5] established the relationship between the largest horizontal displacement and the depth of the excavation pit for clay and sandy soils. Clough and O'Rourke (1990) [6] also studied deep excavation in the Taipei area as a basis for developing a correlation diagram of the largest horizontal displacement of the diaphragm wall with the factor of safety against basal heave of the diaphragm wall and support system. The above charts can be used to predict an estimated displacement of the diaphragm wall in similar conditions.

\subsection{Method of Dependent Pressures and FEM}

The method of dependent pressures and FEM are two common methods for analyzing the horizontal displacement of diaphragm walls in deep excavation pits. The advantage of either methods is the simulation of nearly all factors affecting the horizontal displacement of the diaphragm wall in any deep excavation pits. On the other hand, these two methods can be applied in computer software to reduce the volume and calculation time with more accurate results. However, the basic theory of these two methods is not really simple, especially the FEM, so that the analyst must not only have a strong basic knowledge but also practical experience.

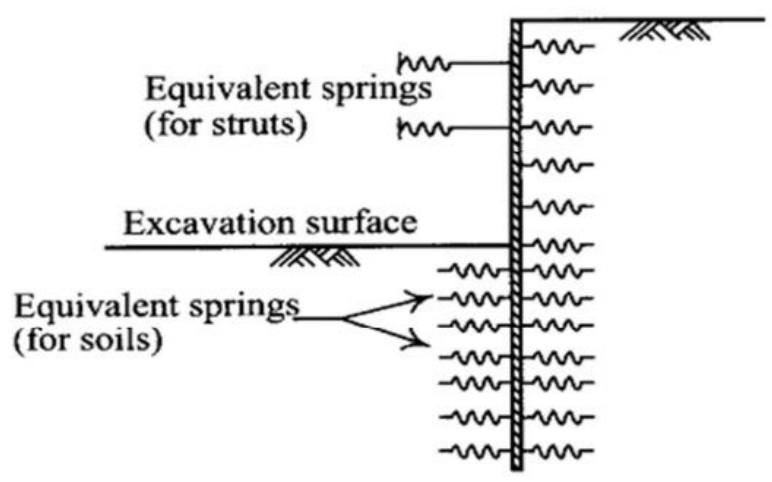

Figure 7. The method of dependent pressures 
Application of the method of dependent pressures and FEM in analyzing the horizontal displacement of diaphragm wall in the deep excavation pit has been studied by some authors. M. Mitew (2006) [12] used the two methods to conduct horizontal displacement analysis of the diaphragm wall in the deep excavation pit (Fig.7).

Using Geo-FEM software, Masew calculated $\mathrm{K}_{\mathrm{h}}$ following the methods of Terzaghi (1955), Menard and Bourdon (1964), and Monnet (1994). For FEM, Mitew used the Mohr Coulomb model and Plaxis 2D software. Mitew divided soil hardness into four cases: FEM 1, soil hardness based on Polish standards; FEM 2, soil hardness based on previous studies; FEM 3, soil hardness based on geological survey results; and FEM 4, soil hardness based on on-site stress measurements. The results are given in Table 1. The results of the analysis were compared with those collected in the field. Mitew reported that the dependent pressure method gave extremely variable results because it is highly dependent on how the coefficient of $K_{h}$ is determined. Meanwhile, the results of FEM had little variation and were close to the monitoring results. However, Mitew also emphasized that the chosen background model and its parameters are crucial when using FEM.

Table 1. The largest horizontal displacement of the wall when analyzing by different methods compared to the observed results, M.Mitew (2005) [12]

\begin{tabular}{|c|c|c|}
\hline \multirow{2}{*}{$\begin{array}{l}\text { Method of } \\
\text { dependent } \\
\text { pressures }\end{array}$} & Terzaghi & $9.2 \mathrm{~mm}$ \\
\cline { 2 - 3 } & Menard and Bourdon & $9.7 \mathrm{~mm}$ \\
\cline { 2 - 3 } & Monnet & $18.9 \mathrm{~mm}$ \\
\hline \multirow{2}{*}{ FEM } & FEM1 & $12.1 \mathrm{~mm}$ \\
\cline { 2 - 3 } & FEM2 & $12.8 \mathrm{~mm}$ \\
\cline { 2 - 3 } & FEM3 & $11.7 \mathrm{~mm}$ \\
\cline { 2 - 3 } & FEM4 & $11.1 \mathrm{~mm}$ \\
\hline Monitor & & $12.3 \mathrm{~mm}$ \\
\hline
\end{tabular}

Krasinski and Urban (2011) conducted a deep excavation analysis using two methods [9]. The first method simulated the interaction between the foundation and the wall with a system of elastic springs, and the authors used Obudowy Głebokich Wykopów software (OGW) to improve on Winkler model. The second method was a FEM that used Plaxis 2D with the Hardening Soil model. Krasinski and Urban found significant differences between methods. For the first method, the authors discovered shortcomings when simulating the behavior of the wall and the foundation with a beam on elastic springs because these elastic springs did not fully describe the complex physical phenomena in the interaction between the wall and the soil. The authors also noted that both methods gave different results. To determine which method is more reliable, we must verify their results with actual monitoring data.

\subsection{Engineering Geological Parameters}

We analyzed the pits belonging to package $\mathrm{G}$, located in SIP1. Our study was a part of the project on improving the water environment in Ho Chi Minh City. For the jacking pit SIP1-15, the physical and mechanical indicators of the soil layer in the study area are given in Table 2. Geological surveying was conducted by the Viet Nam Water, Sanitation, and Environment Joint Stock Company (VIWASE). The physical and mechanical characteristics of the soil layer and the cement-soil piles are collected in Tables $2-4$.

Table 2. Physical and mechanical characteristics of the soil layer

\begin{tabular}{|c|c|c|}
\hline Name of indicator & Layer 2 & Layer 4 \\
\hline Type of soil & Clay & Sandy soil \\
\hline Status & Fluid & Medium stiff \\
\hline Thickness $(\mathrm{m})$ & 5.2 & 43.8 \\
\hline Unit weight $\gamma_{\text {unsat }}\left(\mathrm{kN} / \mathrm{m}^{3}\right)$ & 8.20 & 16.00 \\
\hline Saturated unit weight $\gamma_{\text {sat }}\left(\mathrm{kN} / \mathrm{m}^{3}\right)$ & 15.05 & 20.05 \\
\hline Vertical permeability $\mathrm{k}_{\mathrm{x}}(\mathrm{m} /$ day $)$ & 0.103 & 0.0347 \\
\hline Horizontal permeability $\mathrm{k}_{\mathrm{y}}(\mathrm{m} /$ day) & 0.0637 & 0.00694 \\
\hline Effective secant modulus $\mathrm{E}_{50}\left(\mathrm{kN} / \mathrm{m}^{2}\right)$ & 5670 & 11200 \\
\hline $\begin{array}{c}\text { Effective oedometer modulus } \mathrm{E}_{\text {oed }} \\
\left(\mathrm{kN} / \mathrm{m}^{2}\right)\end{array}$ & 5670 & 11200 \\
\hline $\begin{array}{c}\text { Effective unloading/reloading } \\
\text { modulus } \mathrm{E}_{\text {ur }}\left(\mathrm{kN} / \mathrm{m}^{2}\right)\end{array}$ & 17010 & 33600 \\
\hline Cohesion c' $\left(\mathrm{kN} / \mathrm{m}^{2}\right)$ & 8.10 & 16.00 \\
\hline Internal frictional angle $\varphi($ degree$)$ & 3.22 & 18.82 \\
\hline Intensity reduction coefficient $\mathrm{R}_{\text {inter }}$ & 0.65 & 0.65 \\
\hline $\mathrm{m}$ & 1 & 1 \\
\hline Dilatation angle $\psi($ degree $)$ & 0 & 0 \\
\hline Poisson's ratio $\mathrm{v}$ & 0.30 & 0.30 \\
\hline Material model & $\mathrm{H}-\mathrm{S}$ & $\mathrm{H}-\mathrm{S}$ \\
\hline Behavior of materials & Drained & Drained \\
\hline
\end{tabular}

Table 3. Physical and mechanical parameters of the cement-soil piles of the equivalent foundation model

\begin{tabular}{|c|c|c|}
\hline Name of indicators & $\begin{array}{c}\text { Soil-cement pile } \\
\text { (Layer 2) }\end{array}$ & $\begin{array}{c}\text { Soil-cement pile } \\
\text { (Layer 4) }\end{array}$ \\
\hline$\gamma_{\text {unsat }}\left(\mathrm{kN} / \mathrm{m}^{3}\right)$ & 8.79 & 16.20 \\
\hline$\gamma_{\mathrm{sat}}\left(\mathrm{kN} / \mathrm{m}^{3}\right)$ & 15.40 & 20.15 \\
\hline $\mathrm{k}_{\mathrm{x}}(\mathrm{m} / \mathrm{day})$ & 0.102 & 0.0373 \\
\hline $\mathrm{k}_{\mathrm{y}}(\mathrm{m} / \mathrm{day})$ & 0.0648 & 0.0109 \\
\hline $\mathrm{E}_{50}\left(\mathrm{kN} / \mathrm{m}^{2}\right)$ & 15387 & 20640 \\
\hline $\mathrm{E}_{\text {oed }}\left(\mathrm{kN} / \mathrm{m}^{2}\right)$ & 15387 & 20640 \\
\hline $\mathrm{E}_{\mathrm{ur}}\left(\mathrm{kN} / \mathrm{m}^{2}\right)$ & 36160 & 61920 \\
\hline $\mathrm{c}^{\prime}\left(\mathrm{kN} / \mathrm{m}^{2}\right)$ & 22.70 & 40.20 \\
\hline$\varphi($ degree$)$ & 4.81 & 19.63 \\
\hline $\mathrm{R}_{\text {inter }}$ & 0 & 0 \\
\hline $\mathrm{m}$ & 0.9 & 1 \\
\hline$\psi($ degree $)$ & 0.97 & 0.97 \\
\hline Poisson's ratio $\mathrm{u}$ & 0.30 & 0.25 \\
\hline Material model & $\mathrm{H}-\mathrm{S}$ & $\mathrm{H}-\mathrm{S}$ \\
\hline Behavior of materials & Drained & Drained \\
\hline
\end{tabular}


Table 4. Physical and mechanical parameters of the soil-cement piles of cylinder models working as piles

\begin{tabular}{|c|c|c|c|}
\hline Element & Parameter & Value & Unit \\
\hline Model type & Material type & Elastic & - \\
\hline Elastic modulus & E & $2.00 \mathrm{E}+05$ & $\mathrm{kN} / \mathrm{m}^{2}$ \\
\hline $\begin{array}{c}\text { Horizontal } \\
\text { cross-sectional area }\end{array}$ & A & 0.785 & $\mathrm{~m}^{2}$ \\
\hline Hardness along the axis & EA & $1.57 \mathrm{E}+05$ & $\mathrm{kN} / \mathrm{m}$ \\
\hline Distance & L & 1 & $\mathrm{~m}$ \\
\hline
\end{tabular}

\subsection{Simulation of Steel Sheet Piles Combined with Soil-Cement Piles to Stabilize a Deep Excavation Pit Wall}

\subsubsection{Construction sequence of an excavation pit}

The construction sequence of an excavation pit is shown in Table 5.

Table 5. Construction sequence of an excavation pit

\begin{tabular}{|c|c|}
\hline Step & Works to be done \\
\hline 0 & The initial state of the soil $(+0.0 \mathrm{~m})$ \\
\hline 1 & Construction of the Larsen diaphragm wall \\
\hline 2 & Construction of soil-cement wall \\
\hline 3 & $\begin{array}{l}\text { Construction of bouchon with } 2 \mathrm{~m} \text { soil-cement piles } \\
\qquad(-22.0 \mathrm{~m} \text { to }-20.0 \mathrm{~m})\end{array}$ \\
\hline 4 & Construction of the first strut floor $(+0.0 \mathrm{~m})$. \\
\hline 5 & $\begin{array}{l}\text { Lowering the underground water level, construction of the } \\
\text { first excavation ( } 3 \mathrm{~m} \text { of soil) to the elevation of }-3.0 \mathrm{~m}\end{array}$ \\
\hline 6 & Construction of the second strut floor $(-3.0 \mathrm{~m})$. \\
\hline 7 & $\begin{array}{l}\text { Lowering the underground water level, construction of the } \\
\text { second excavation ( } 3 \mathrm{~m} \text { of soil) to the elevation of }-6.0 \mathrm{~m}\end{array}$ \\
\hline 8 & Construction of the third strut floor $(-6.0 \mathrm{~m})$. \\
\hline 9 & $\begin{array}{l}\text { Lowering the underground water level, construction of the } \\
\text { third excavation ( } 3 \mathrm{~m} \text { of soil) to the elevation of }-9.0 \mathrm{~m}\end{array}$ \\
\hline 10 & Construction of the fourth strut floor $(-9.0 \mathrm{~m})$. \\
\hline 11 & $\begin{array}{l}\text { Lowering the underground water level, construction of the } \\
\text { fourth excavation ( } 3 \mathrm{~m} \text { of soil) to the elevation of }-12.0 \mathrm{~m}\end{array}$ \\
\hline 12 & Construction of the fifth strut floor $(-12.0 \mathrm{~m})$. \\
\hline 13 & $\begin{array}{l}\text { Lowering the underground water level, construction of the } \\
\text { fifth excavation ( } 3 \mathrm{~m} \text { of soil) to the elevation of }-15.0 \mathrm{~m}\end{array}$ \\
\hline 14 & Construction of the sixth strut floor $(-15.0 \mathrm{~m})$. \\
\hline 15 & $\begin{array}{l}\text { Lowering the underground water level, construction of the } \\
\text { sixth excavation ( } 3 \mathrm{~m} \text { of soil) to the elevation of }-18.0 \mathrm{~m}\end{array}$ \\
\hline 16 & Construction of the seventh strut floor $(-18.0 \mathrm{~m})$. \\
\hline 17 & $\begin{array}{l}\text { Lowering the underground water level, construction of the } \\
\text { seventh excavation ( } 3 \mathrm{~m} \text { of soil) to the elevation of }-20.0 \mathrm{~m}\end{array}$ \\
\hline
\end{tabular}

\subsubsection{Simulations using Midas GTS NX software}

The Larsen sheet piles diaphragm wall was pressed down to a depth of $30 \mathrm{~m}$. Cross and longitudinal sections of the strut in the excavation pit are shown in Figs. 8-11. Details on the steel sheet piles reinforcing the excavation pit wall and the parameters of the struts are displayed in Tables 6-7.

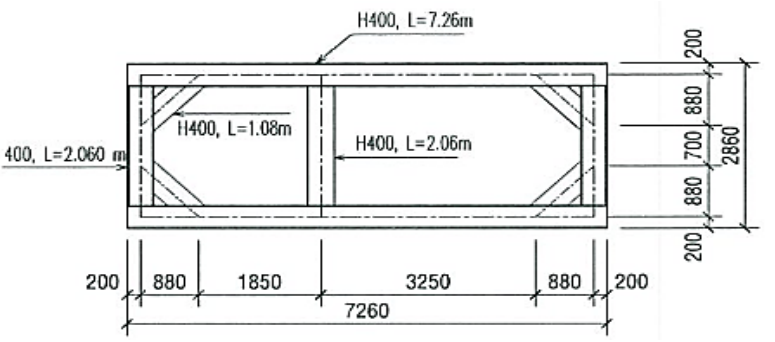

Figure 8. Cross section of the strut in the excavation pit

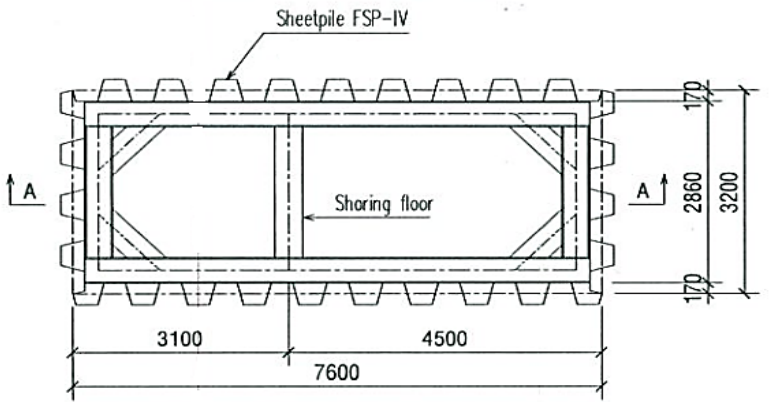

Figure 9. Cross section of the strut in the excavation pit combined with Larsen sheet piles

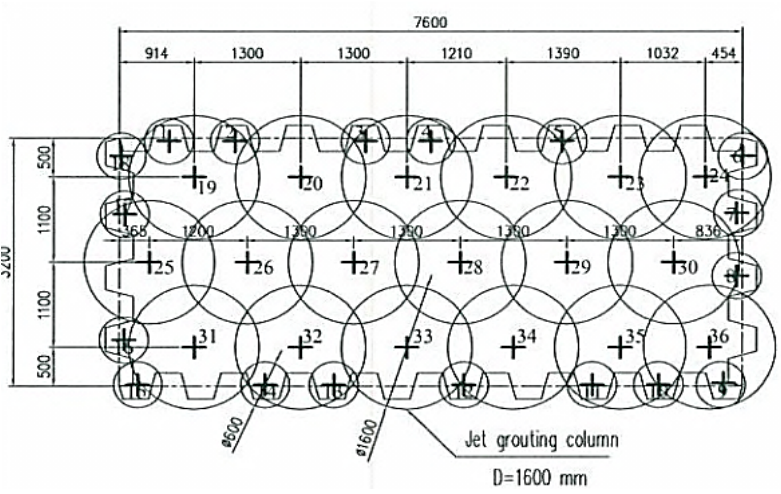

Figure 10. Cross section of the bottom of the excavation pit 


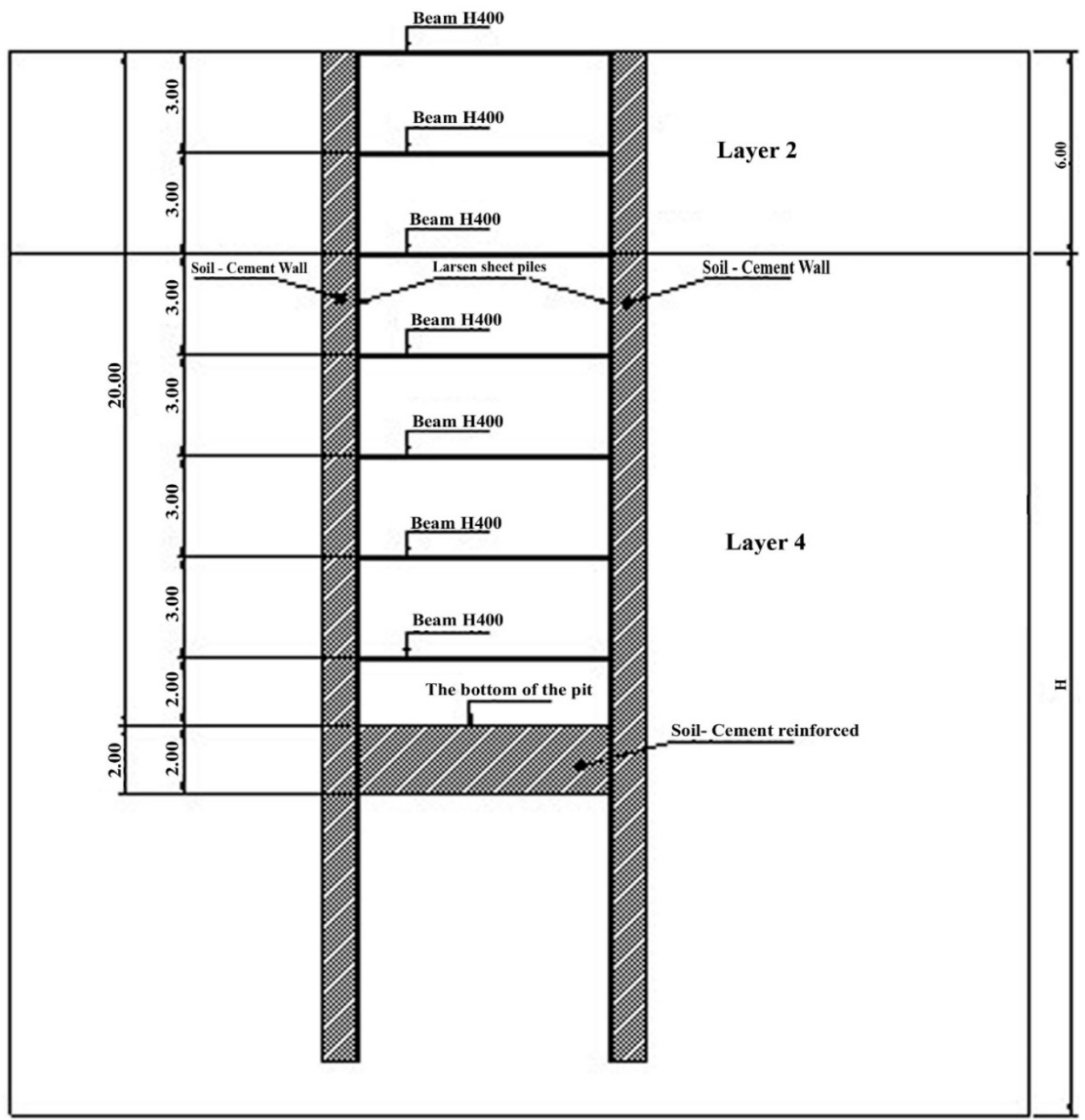

Figure 11. Longitudinal section of the excavation pit

Table 6. Specification of steel sheet piles reinforcing the excavation pit's wall

\begin{tabular}{|c|c|c|c|}
\hline Element & Parameter & Larsen sheet piles & Unit \\
\hline Model type & Material type & Elastic & $\mathrm{kN} / \mathrm{m}^{2}$ \\
\hline Elastic modulus & E & $21 \mathrm{E}+07$ & $\mathrm{~cm}^{2}$ \\
\hline Horizontal cross-sectional area & A & 242.50 & $\mathrm{~cm}^{4}$ \\
\hline Moment of inertia & $\mathrm{I}=\left(\mathrm{b}^{2} \mathrm{~d}^{3}\right) / 12$ & 38600 & $\mathrm{~cm}$ \\
\hline Thickness & $\mathrm{d}$ & 1.55 & $\mathrm{~cm}$ \\
\hline Height & $\mathrm{H}$ & 17.00 & $\mathrm{kN} / \mathrm{m} / \mathrm{m}$ \\
\hline Weight & w & 7.6 & - \\
\hline
\end{tabular}

Table 7. Parameters of the struts: pits were constructed with struts $\mathrm{H} 400 * 400 * 13 * 21$

\begin{tabular}{|c|c|c|c|}
\hline Element & Parameter & Value & Unit \\
\hline Model type & Material type & Elastic & $\mathrm{kN} / \mathrm{m}^{2}$ \\
\hline Elastic modulus & E & $2.10 \mathrm{E}+08$ & $\mathrm{~m}^{2}$ \\
\hline Horizontal cross-sectional area & A & $2.187 \mathrm{E}-02$ & $\mathrm{kN}$ \\
\hline Stiffness along the axis & EA & $4.59 \mathrm{E}+06$ & $\mathrm{~m}$ \\
\hline Distance & L & 3 & \\
\hline
\end{tabular}




\section{Results and Discussion}

\subsection{Results}

The results of using the Equivalent Material Simulation method (EMS) method on the Larssen sheet piles wall are illustrated in Figs. 12-14. The results of using the Real Allocation Simulation method (RAS) to determine the internal forces acting on a Larssen sheet piles wall are shown in Figs 15-17.
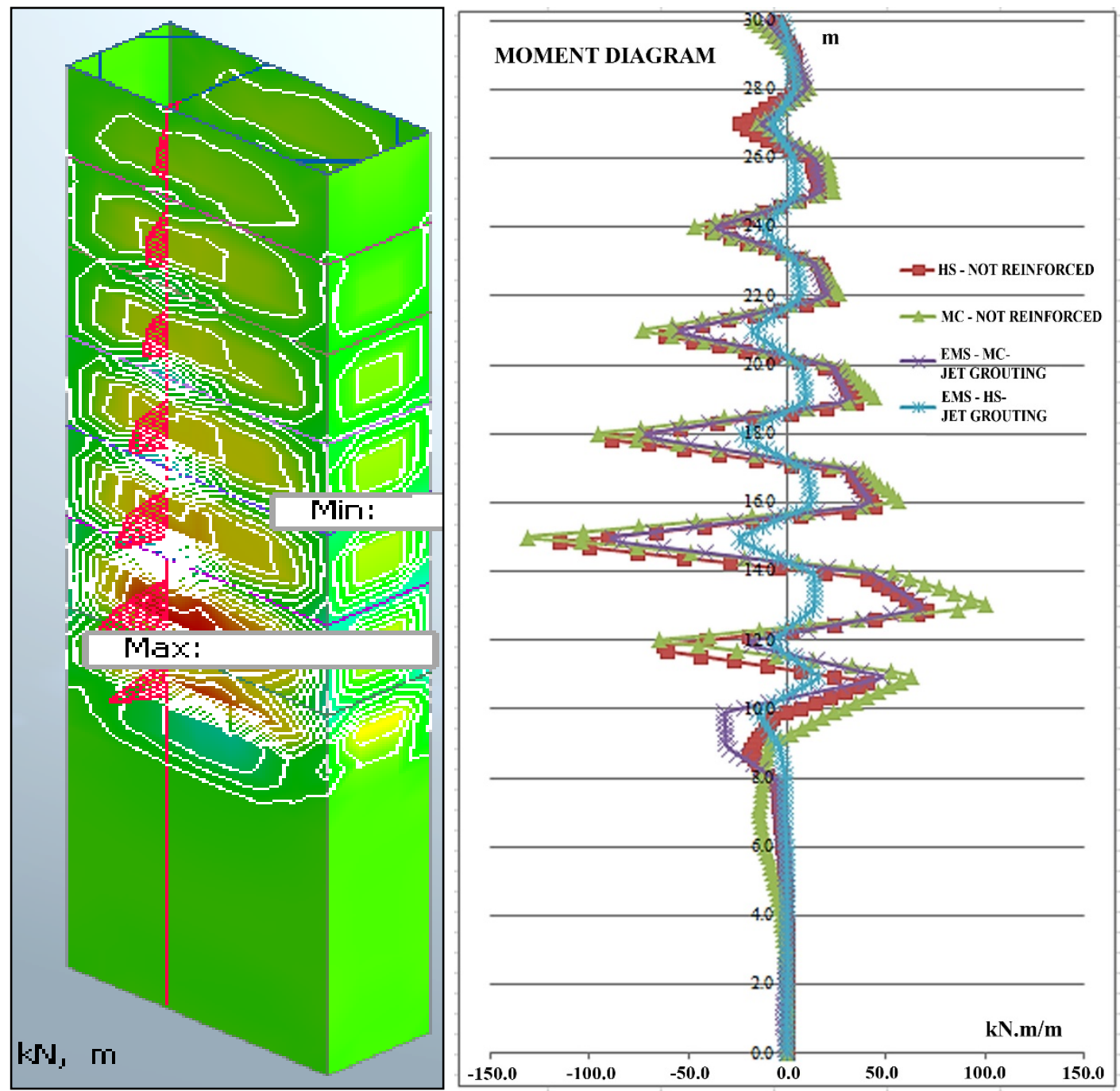

Figure 12. Moment diagram of the longitudinal aspect of Larsen sheet pile’s diaphragm wall according to Mohr Coulomb model and Hardening Soil model 

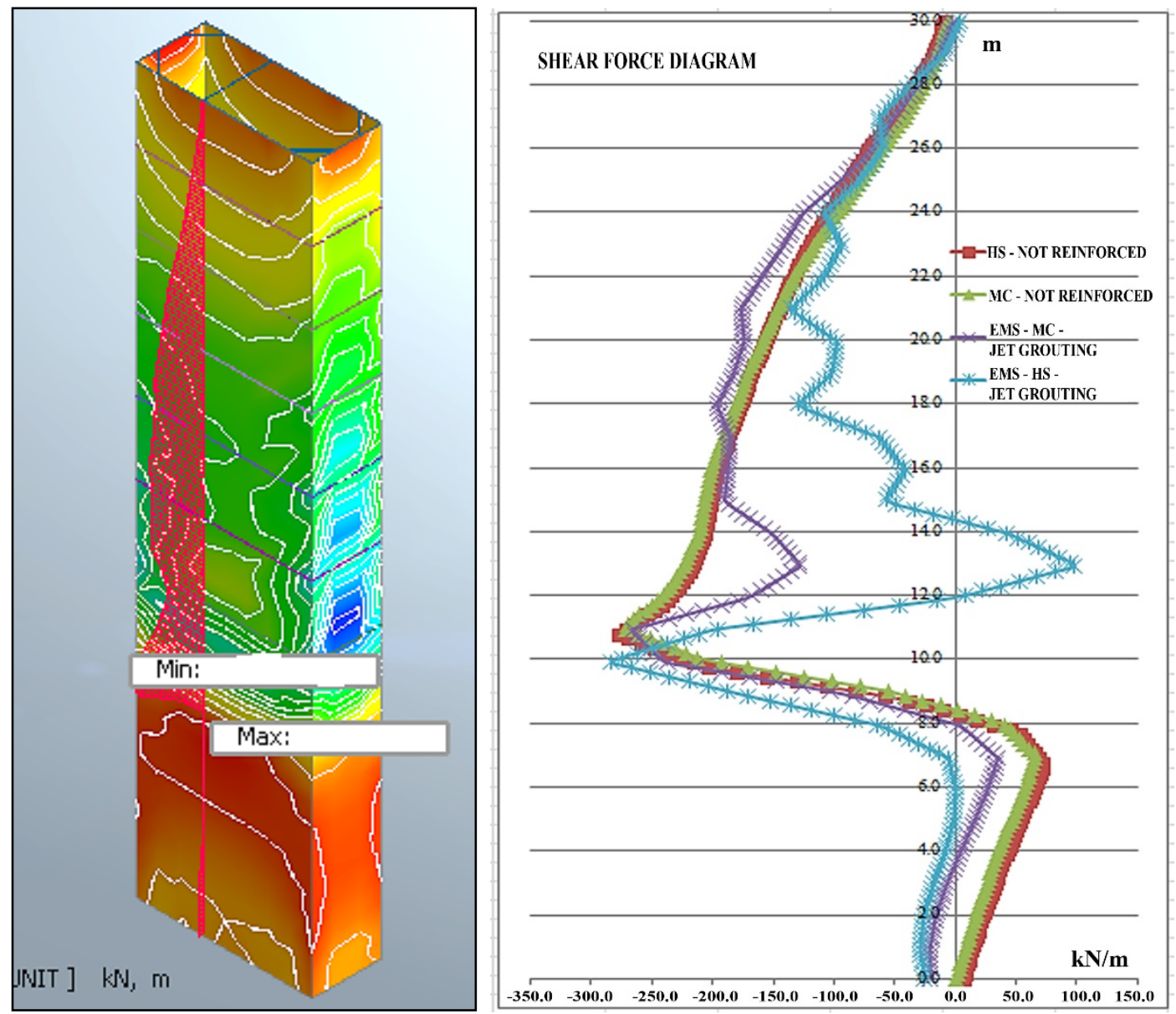

Figure 13. Shear force diagram of the longitudinal aspect of Larsen sheet piles' diaphragm wall according to Mohr Coulomb model and Hardening Soil model 

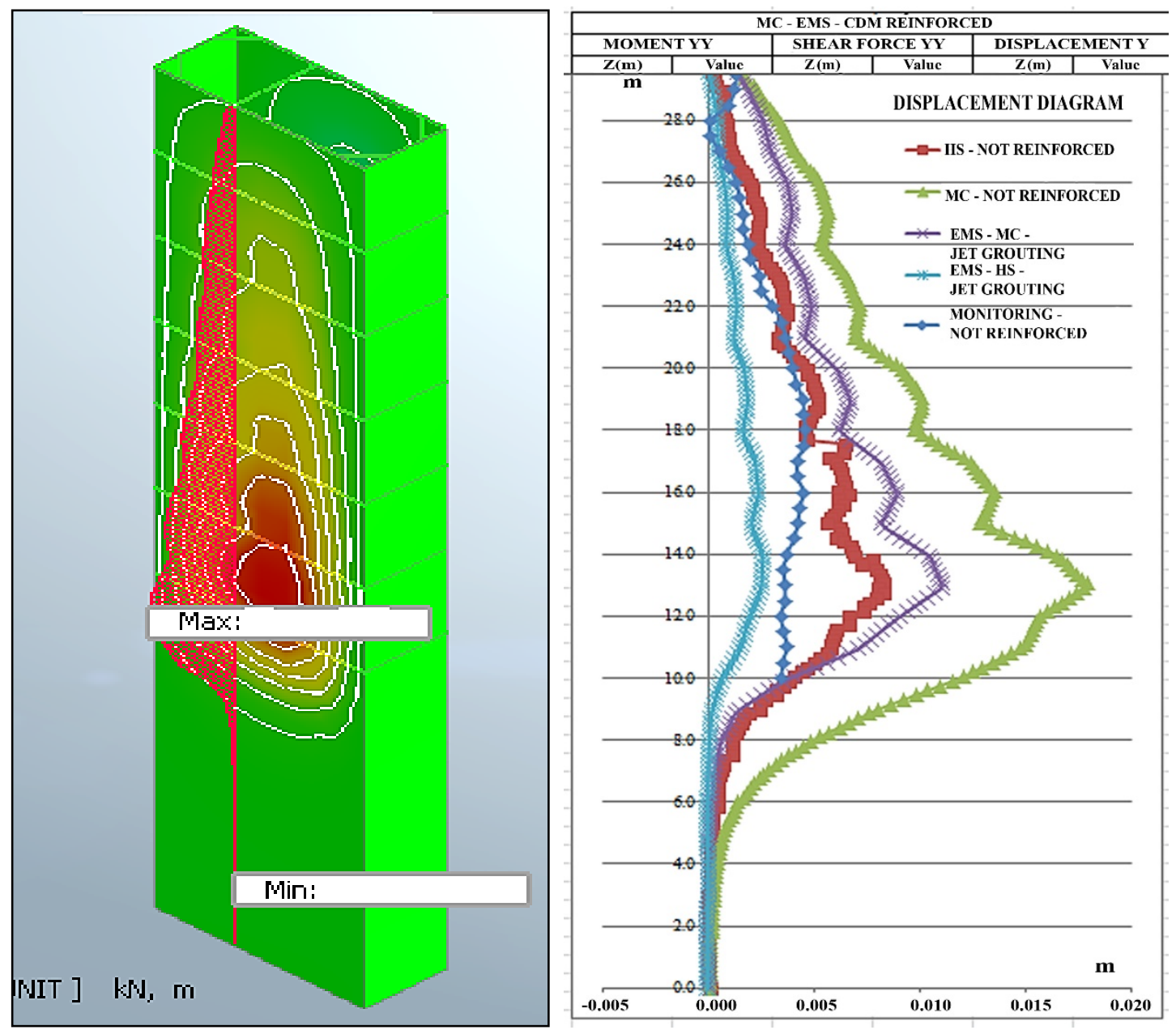

Figure 14. Displacement diagram of the longitudinal aspect of Larsen sheet spiles’ diaphragm wall according to Mohr Coulomb model and Hardening Soil model 

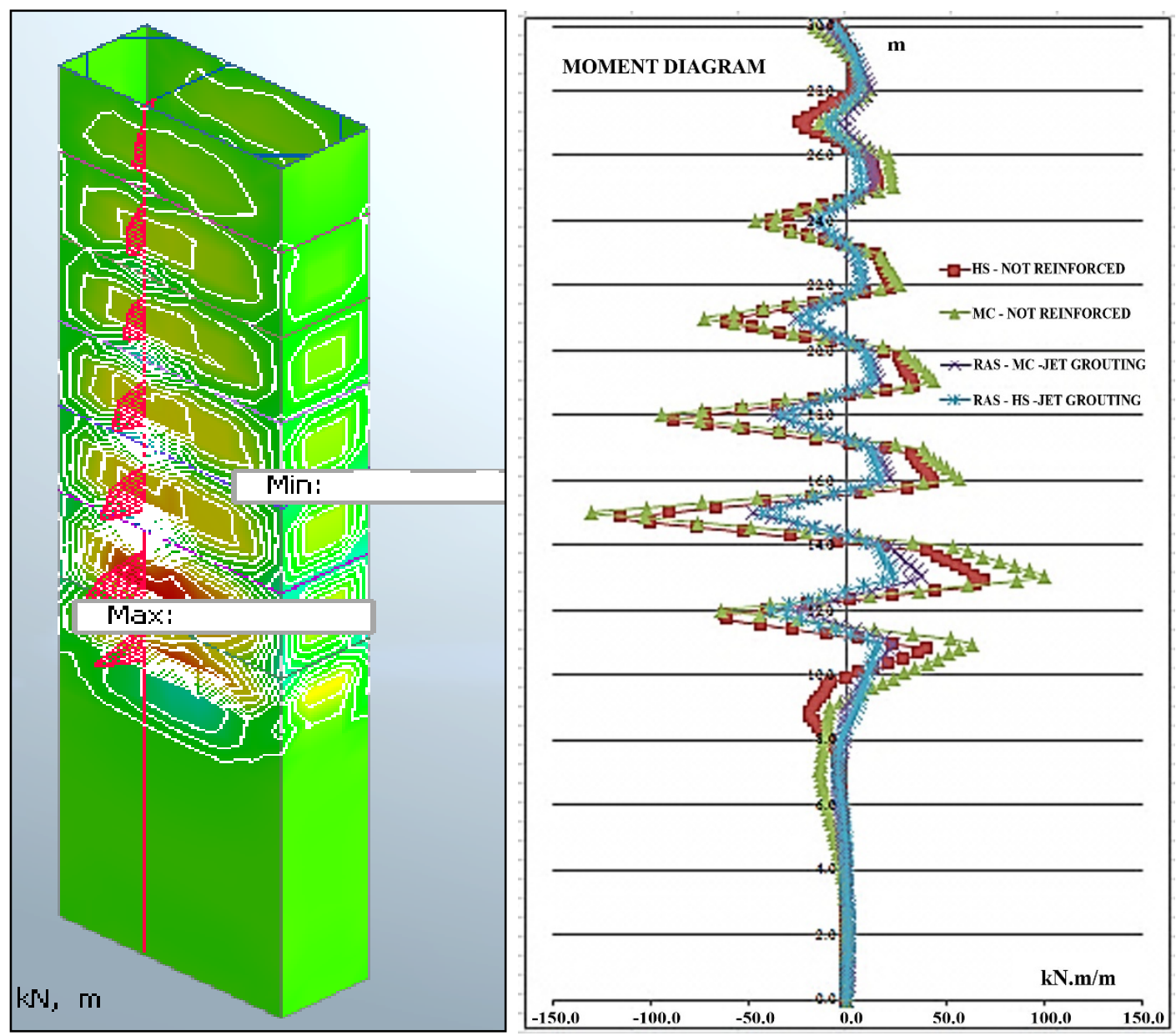

Figure 15. Moment diagram of the longitudinal aspect of Larsen sheet piles’ diaphragm wall according to Mohr Coulomb model and Hardening Soil model

Figs. 18-19 illustrate the effects of ground surface displacement when the excavation pit wall has not been reinforced by soil-cement piles. Figs. 20-21 demonstrate the effects of ground surface displacement when the excavation pit wall has been reinforced by soil-cement piles that comply with EMS. Figs. 22-23 show the effects of foundation-surface displacement when the excavation pit wall has been reinforced with soil-cement piles following the RAS method. 

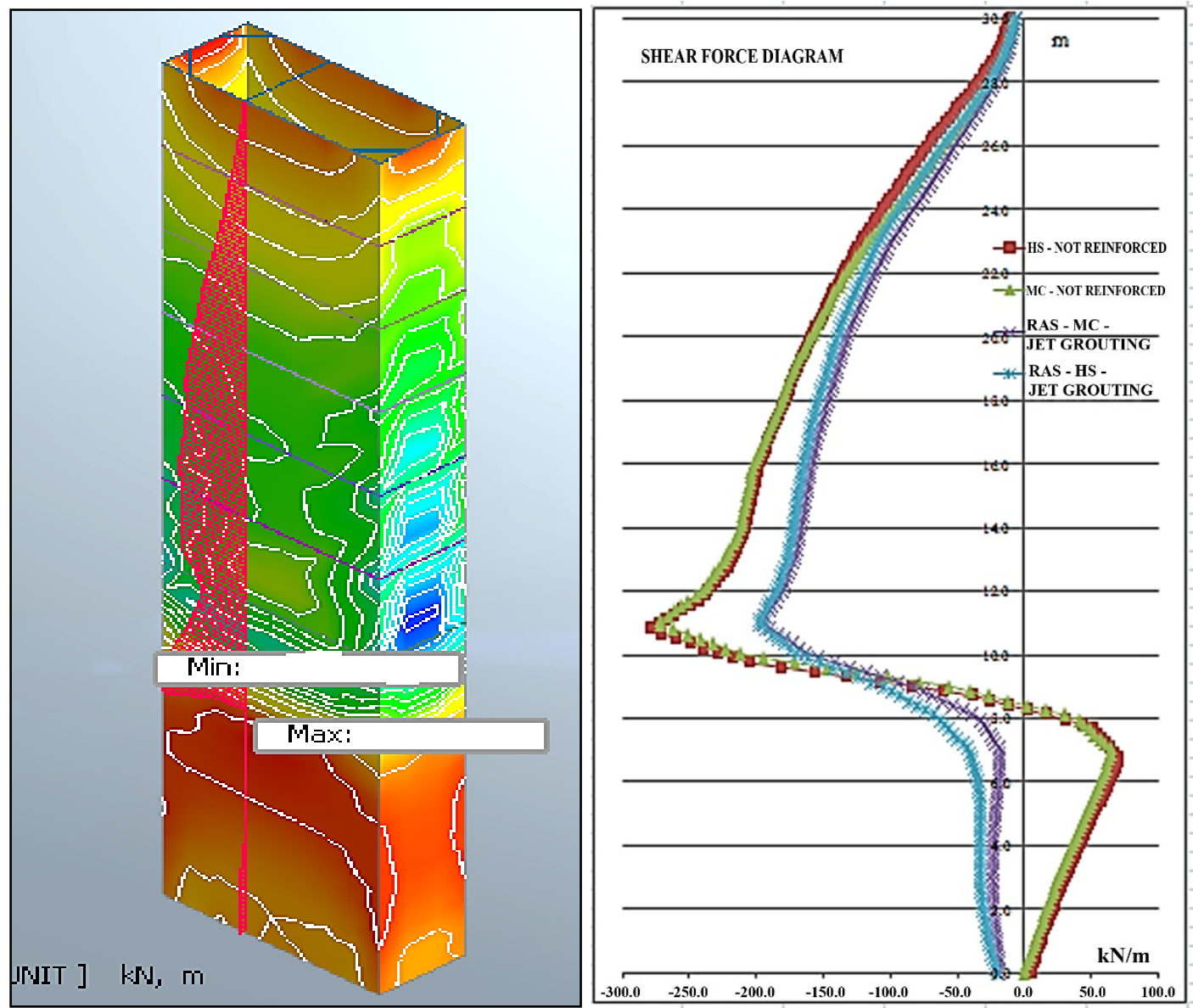

Figure 16. Shear force diagram of the longitudinal aspect of Larsen sheet piles’ diaphragm wall according to Mohr Coulomb model and Hardening Soil model 

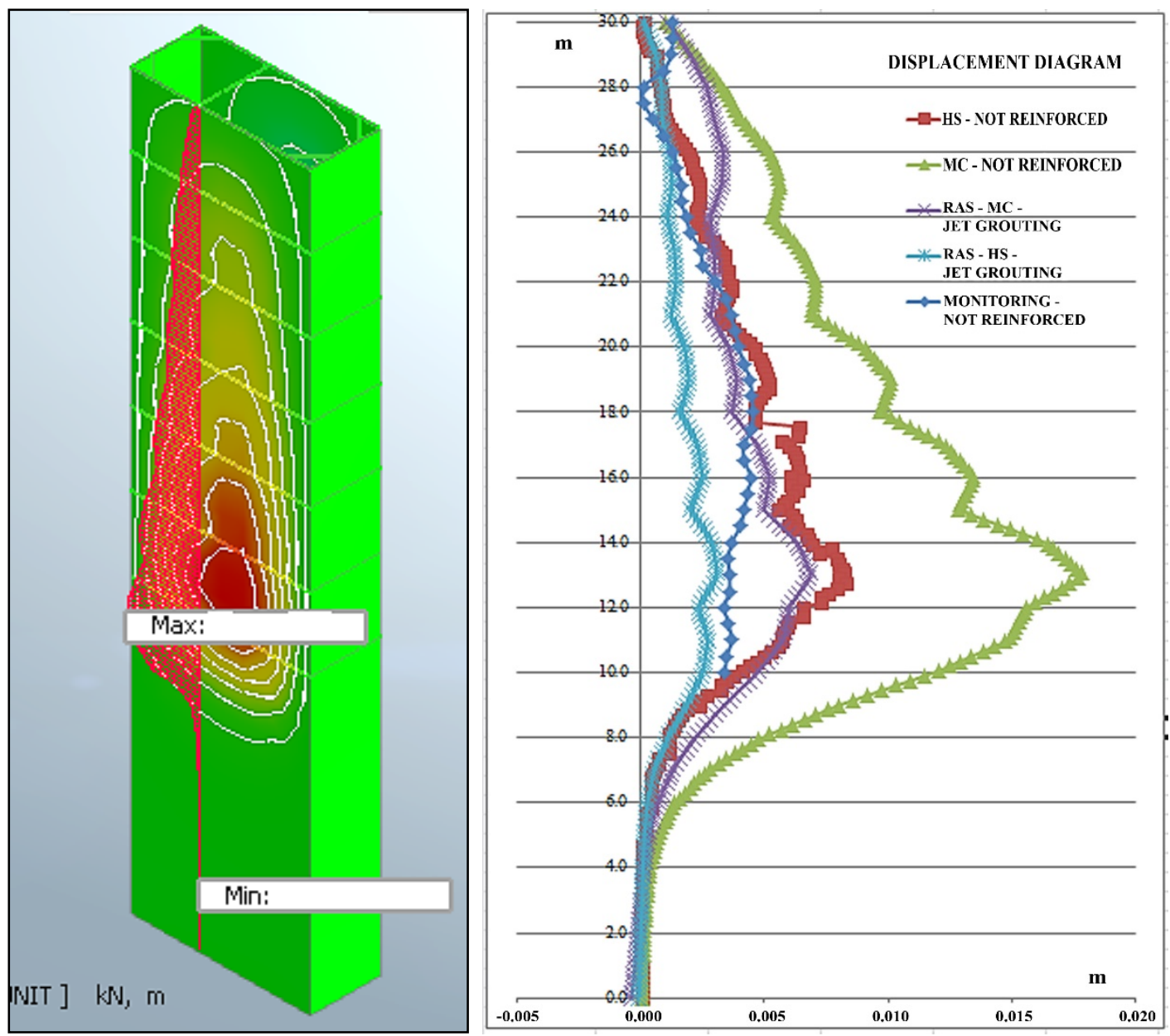

Figure 17. Displacement diagram of longitudinal aspect of Larsen sheet piles’ diaphragm wall according to Mohr Coulomb model and Hardening Soil model 


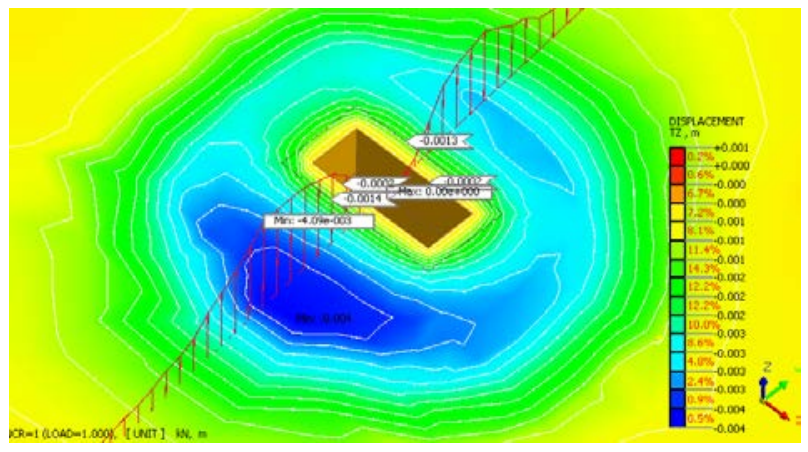

Figure 18. Longitudinal section of the excavation pit

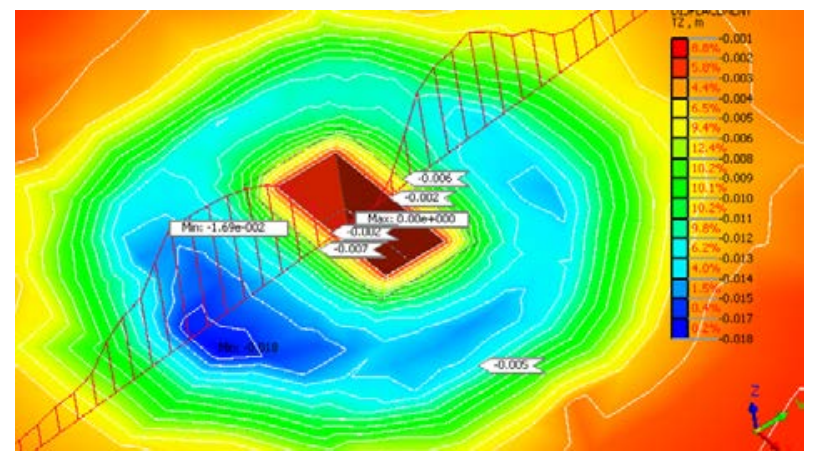

Figure 19. The result of vertical displacement of the foundation according to the MC model when the excavation pit's wall has not been reinforced by soil-cement piles

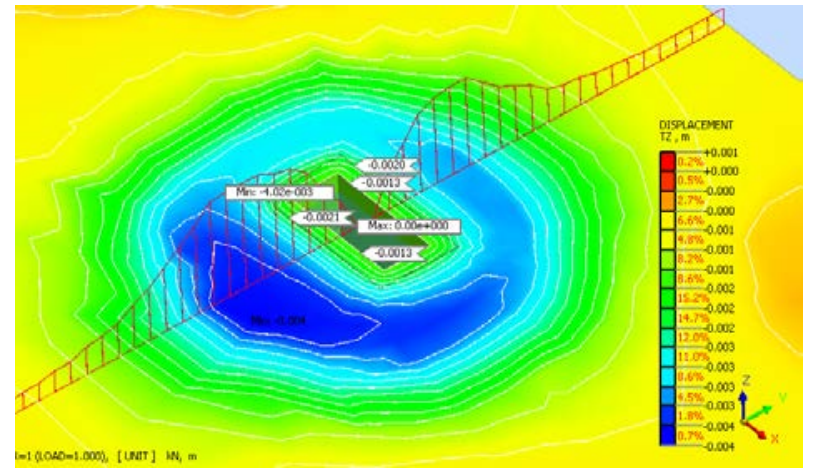

Figure 20. The result of vertical displacement of the foundation according to the HS model when the excavation pit's wall has been reinforced with soil-cement piles

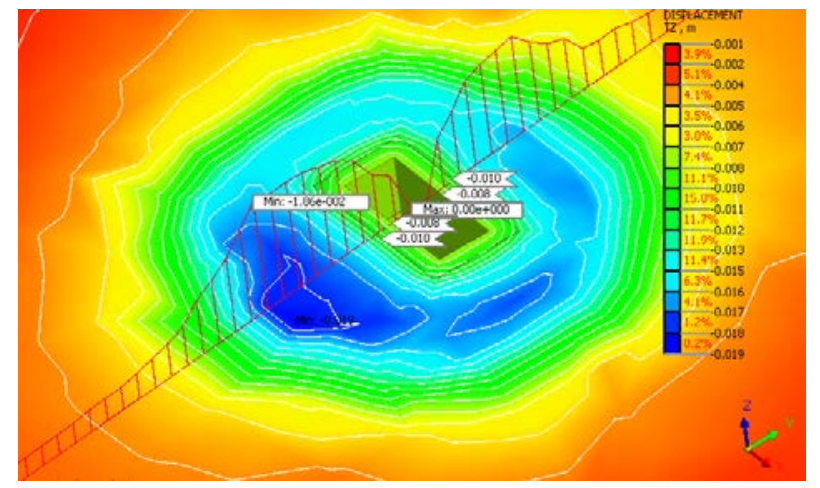

Figure 21. The result of vertical displacement of the foundation according to the MC model when the excavation pit's wall has been reinforced with soil-cement piles

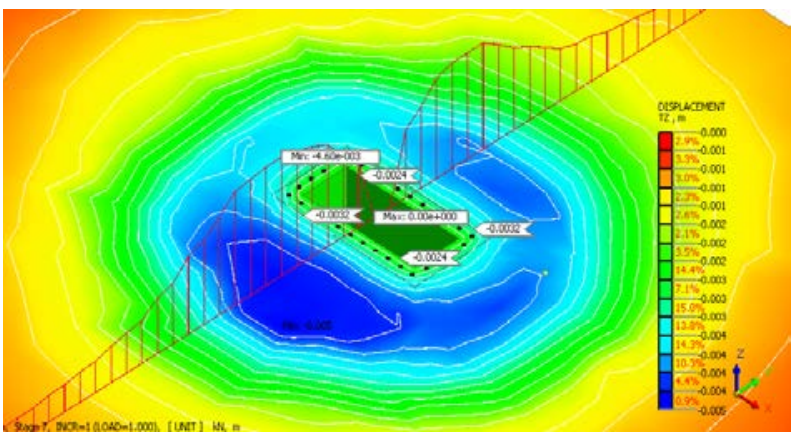

Figure 22. The result of vertical displacement of the foundation according to the HS model when the excavation pit's wall has been reinforced with soil-cement piles

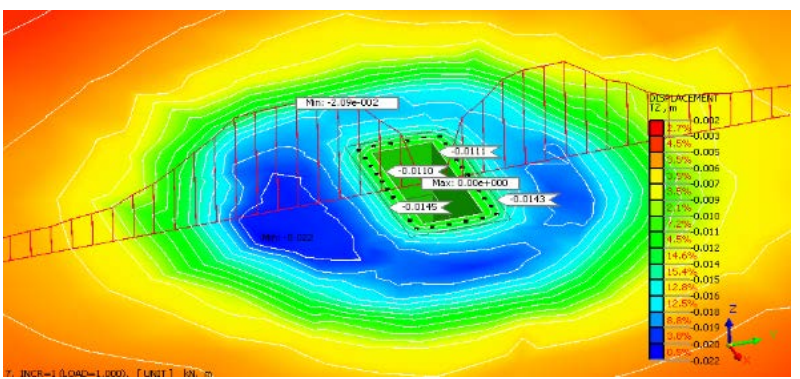

Figure 23. The result of vertical displacement of the foundation according to the MC model when the excavation pit's wall has been reinforced with soil-cement piles

\subsection{Discussion}

\subsubsection{The internal force of Larsen sheet piles' wall}

When a wall was not reinforced by soil-cement piles $800 \mathrm{~mm}$ in diameter (D800), the Mohr-Coulomb model gave the following result for the maximum moment in the wall: $\mathrm{M}=131.241 \mathrm{kN} \cdot \mathrm{m} / \mathrm{m}<[\mathrm{M}]=476.70 \mathrm{kN} \cdot \mathrm{m} / \mathrm{m}$. The moment is within the permitted range. In contrast, the analytical method gave the following result: $\mathrm{M}=140.35$ $\mathrm{kN} \cdot \mathrm{m} / \mathrm{m}$ (difference of $6.94 \%$ ). Therefore, we concluded that the ground simulated by the Mohr-Coulomb model has results similar to those of the analytical model. The Hardening Soil model gave the highest equal value for the shear force in the unreinforced pile wall: $Q=277.74$ $\mathrm{kN} / \mathrm{m}$. In comparison, the analytical method gave the following result: $\mathrm{Q}=286.10 \mathrm{kN} / \mathrm{m}$ (difference of $3 \%$ ). Based on these results, we determined that the results of the finite element model using Midas GTS NX software are equivalent those of analytical methods.

We also tested models on the excavation pit stabilized by soil-cement and steel piles. We modeled the problem of combining soil-cement and steel sheet piles to stabilize the excavation pit using the EMS method. The Mohr Coulomb model gave the maximum moment in the sheet-steel pile wall, $M=88.657 \mathrm{kN} \cdot \mathrm{m} / \mathrm{m}$, while the Hardening Soil model delivered a lower value, $M=24.083$ $\mathrm{kN} \cdot \mathrm{m} / \mathrm{m}$. This difference indicates that a sheet steel pile wall is most dangerous when the Mohr Coulomb model is used as its soil model. Shear forces in reinforced walls 
have the same value in Mohr-Coulomb model as $\mathrm{Q}=$ $265.492 \mathrm{kN} / \mathrm{m}$, and Hardening Soil Q = $283.25 \mathrm{kN} . \mathrm{m} / \mathrm{m}$.

- When modeling a combination of soil-cement piles and steel sheet piles to stabilize the excavation pit by the RAS method, it can be found that the Mohr-Coulomb model gives the maximum moment in the sheet steel pile's wall, $\mathrm{M}=48.754 \mathrm{kN} \cdot \mathrm{m} / \mathrm{m}$, while the Hardening Soil model delivers $\mathrm{M}=43.437$ $\mathrm{kN} \cdot \mathrm{m} / \mathrm{m}$. This difference shows that the sheet steel pile's wall is the most dangerous when the soil model is Mohr-Coulomb. Shear forces in reinforced walls have the same value for the Mohr-Coulomb model as $\mathrm{Q}=194.02 \mathrm{kN} / \mathrm{m}$ and Hardening Soil $\mathrm{Q}=$ $196.679 \mathrm{kN} \cdot \mathrm{m} / \mathrm{m}$.

\subsubsection{The displacement in Larsen sheet piles' wall}

- When the excavation pit's wall has not been reinforced by soil-cement piles through comparison between the two models of MC, HS and monitoring results, it was found that the HS model gives results closer to the monitoring results (the most displacement position above the distance from the bottom of the pit of 2-3 m). When the excavation pit's wall has been reinforced by soil-cement piles, the displacement of steel sheet piles will decrease.

\subsubsection{Ground surface displacement}

When the bottom of the excavation pit has been reinforced, but the excavation pit's wall has not been reinforced, the settlement of the outer edge and the inside edges of the reinforced soil-cement piles' walls have a large and uneven difference. When combining soil-cement piles and steel sheet piles, the settlement is reduced and uniformly distributed, while the settlement within the zone of reinforced soil-cement piles increases because the soil layer has been reinforced with cement; thus the self-load is larger, with $\gamma=21 \mathrm{kN} / \mathrm{m}^{3}$, compared to the existing layer 2 with $\gamma=14.8 \mathrm{kN} / \mathrm{m}^{3}$ and layer 4 with $\gamma=$ $20.5 \mathrm{kN} / \mathrm{m}^{3}$.

\section{Conclusions}

Through this research and analysis, the author gave a general conclusion about the research content, evaluation of the application of sheet piles combined with soil-cement piles to stabilize a deep excavation pit's wall in the Ho Chi Minh City water environment improvement project as below.

1) Combination of soil-cement piles and steel sheet piles reduces the horizontal displacement of steel sheet piles' walls.

- $\quad$ By EMS method: The Mohr-Coulomb model has the largest horizontal displacement when the excavation pit's wall has not been reinforced by soil-cement piles D800 with $\mathrm{T}_{\mathrm{y}}$ value equal
$0.018 \mathrm{~m}$, decreasing by $38.89 \%$ to $\mathrm{T}_{\mathrm{y}}=0.011 \mathrm{~m}$ (17 $\mathrm{m}$ from the excavation pit mouth). The Hardening Soil model has the largest horizontal displacement when the excavation pit's wall has not been reinforced by D800 cement soil piles, with the $\mathrm{T}_{\mathrm{y}}$ value of $0.008 \mathrm{~m}$ decreasing by

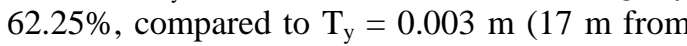
the excavation pit mouth).

- By RAS method: The Mohr-Coulomb (MC) model has the largest horizontal displacement when the wall of the excavation pit has not been reinforced by D800 soil-cement piles. The $\mathrm{T}_{\mathrm{y}}$ value $=0.018 \mathrm{~m}$, which decreases by $61.11 \%$ to $\mathrm{T}_{\mathrm{y}}=0.007 \mathrm{~m}$ (16.95 $\mathrm{m}$ from the excavation pit mouth). The hardening soil (HS) model has the largest horizontal displacement when the wall of the excavation pit has not been reinforced by D800 soil-cement piles. The $\mathrm{T}_{\mathrm{y}}$ value of $0.008 \mathrm{~m}$ decreases by $50 \%$ to $\mathrm{T}_{\mathrm{y}}=0.004 \mathrm{~m}(17.25 \mathrm{~m}$ from the excavation pit mouth).

2) A combination of soil-cement piles and steel sheet piles not only reduces horizontal displacement but also keeps the settlement of the soil around the excavation pit within the permissible range. This ensures the stability of the surrounding pavement and therefore prevents cracks.

- By EMS method: In the MC model, the maximum surface settlement of $\mathrm{T}_{\mathrm{z}}=0.019 \mathrm{~m}$ decreases by $47.36 \%$ to $T_{z}=0.010 \mathrm{~m}$ (located far from the outer edge of the soil-cement piles). The HS model has the largest surface settlement of $\mathrm{T}_{\mathrm{z}}=0.004 \mathrm{~m}$, which decreases by $47.5 \%$ to $\mathrm{T}_{\mathrm{y}}$ $=0.0021 \mathrm{~m}$ (located at the outer edge of the soil-cement piles).

- By RAS method: In the MC model, the maximum surface settlement of $\mathrm{T}_{\mathrm{z}}=0.022 \mathrm{~m}$ decreases by $34.09 \%$ to $\mathrm{T}_{z}=0.0145 \mathrm{~m}$ (located far from the outer edge of the soil-cement piles). The HS model has the largest surface settlement of $\mathrm{T}_{\mathrm{z}}=0.005 \mathrm{~m}$, which decreases by $36 \%$ to $\mathrm{T}_{\mathrm{y}}$ $=0.0032 \mathrm{~m}$ (located at the outer edge of the soil-cement piles).

3) A combination of soil-cement piles and steel sheet piles reduces the internal force of the steel sheet pile walls.

- By EMS method: In the MC model, the maximum moment in the steel sheet pile walls is $\mathrm{M}=88.657 \mathrm{kN} \cdot \mathrm{m} / \mathrm{m}$, which decreases by $32.44 \%$. The shear force $\mathrm{Q}=265.492 \mathrm{kN} / \mathrm{m}$, which decreases by $1.93 \%$. In the HS model, $\mathrm{M}$ $=24.083 \mathrm{kN} \cdot \mathrm{m} / \mathrm{m}$, which decreases by $79.10 \%$. The shear force $\mathrm{Q}=283.25 \mathrm{kN} / \mathrm{m}$, which increases by $1.98 \%$

- By RAS method: In the MC model, the maximum moment in the steel sheet pile walls is 
$\mathrm{M}=48.754 \mathrm{kN} \cdot \mathrm{m} / \mathrm{m}$, which decreases by $62.85 \%$. The shear force $\mathrm{Q}=194.04 \mathrm{kN} / \mathrm{m}$, which decreases by $28.32 \%$. In the HS model, $\mathrm{M}$ $=43.437 \mathrm{kN} \cdot \mathrm{m} / \mathrm{m}$, which decreases by $62.32 \%$. The shear force $\mathrm{Q}=196.679 \mathrm{kN} / \mathrm{m}$, which increases by $29.18 \%$

In addition, the wall of soil-cement piles has a horizontal waterproofing effect on the excavation pit (preventing water from flowing into the pit), with a permeability coefficient of $\mathrm{k}=0.0864 \mathrm{~m} /$ day. Therefore, it is used extensively in irrigation, infrastructure, and construction works for waterproofing of dike banks and diaphragm walls.

\section{REFERENCES}

[1] An, C.N. Soil Mechanic. National University of Ho Chi Minh City Publisher, 2009.

[2] Anh, N.D. Study on the application of steel sheet piles combined with soil-cement piles to stabilize a deep excavation pit's wall for Ho Chi Minh City water environment improvement project. Master Thesis. Ho Chi Minh City University of Transport, 2019.

[3] K.J. Bakker. 3D FEM Model for Excavation Analysis. Presented at the Geotechnical Aspects of Underground Construction in Soft Ground Amsterdam, Sess.4, pp.13-18, 2005

[4] Bowels, J.E. Foundation Analysis and Design, Fifth Edition. Columbus, USA: MacGraw-Hill Publishing Company, 1998.

[5] Chang-Yu Ou. Deep Excavation. Theory and Practice, Taipei, Taiwan: Taylor\& Francis Group, 2006.

[6] Clough, G.W.O’Rourke, T.D. Construction- induced movements of in situ wall. Design and Performance of Earth Retaining Structures.ASCE Special Publication, No.25, pp.439-470, 1990.

[7] HAI, N.V., Nghia, L.T. Behavior of soil-cement pile's diaphragm wall for deep excavation pits on soft ground in District 7 of Ho Chi Minh City. Presented at the 11th Conference of Science and Technology, Faculty of Civil Engineering, Ho Chi Minh City University of Technology, 2009.

[8] Hans-Geord Kempfert, Berhane Gebreselassie. Excavations and Foundations in Soft Soil. Springer-Verlag Berlin Heidelberg, 2006.

[9] A. Krasinky, M. Urban. The results of analysis of deep excavation walls using two different methods of calculation.
Archives of Civil Engineering, pp.59- 72, 2011.

[10] Look. B. Handbook of geotechnical investigation and design tables. London, UK: Taylor \& Francis, 2007.

[11] Lumir Mica, Vaclav Racansky, Juraj Chalmovsky. Technological tunnel centre-Numerical analysis by using different constitutive models. Presented at the 10th International Conference, Vilnius, Lithuania, pp 1146-1152, 2011.

[12] M. Mitew. Numerical analysis of displacement of diaphragm wall. Geotechnical aspects of underground construction in soft ground, pp.615- 62, Tailor \& Francis, London, UK, 2006.

[13] Nghia, L.T., Tai, T.D. Analysis of the effectiveness of soil-cement piles against horizontal displacement of excavation pit's walls in soft soil. Geotechnical Engineering, 2016.

[14] Nghia, L.T., Huu, N.A. Analysis of horizontal displacement of diaphragm wall of deep excavation pit with the bottom of the pit reinforced by cement piles. Geotechnical Engineering, pp. 25-33, 2014.

[15] Tan Y.C., Liew S.S., Gue S.S. A Numerical Analysis of Anchored Diaphragm Walls for a Deep Basement in Kuala Lumpur, Malaysia. Presented at the 14th SEAGC, Hong Kong, 2001.

[16] Nguyen Ngoc Thang, Nguyen Anh Tuan. Nonlinear fem analysis of cement column configuration in the foundation improved by deep mixing method, Strength of Materials and Theory of Structures, No. 100, pp. 18-26, 2018.

[17] Nguyen Anh Tuan, Nguyen Thanh Dat. 2D Finite Element Analysis for the Application of Deep Soil Mixing Columns for Reinforcement of Soft Ground Surrounding Deep Excavation. Presented at the 2020 IEEE 3rd International Conference on Information and Computer Technologies (ICICT), pp. 376-379, 2020.

[18] Trung, N.D., Phan, V. Analysis of the effect of the foundation model to predict displacement and deformation of deep excavation works stabilized by diaphragm walls. Presented at the 12th Conference on Science and Technology, Faculty of Civil Engineering, Ho Chi Minh City University of Technology, 2011.

[19] TCVN 9403-2012, Stabilization of soft soil - The soil cement column method, 2012.

[20] H.F. Schweiger. Results from numerical benchmark exercises in geotechnics. Institute for Soil Mechanics and Foundation Engineering. Graz University of Technology, Austria, 2002.

[21] Tuan Anh Nguyen, Thang Ngoc Nguyen (2020). Study on Stress Distribution in Soft Ground Consolidated with Deep Cement Mixing Columns under Road Embankment. Civil Engineering and Architecture, 8(6), 1251 - 1265. DOI: 10.13189/cea.2020.080609. 